Ambiente \& Água - An Interdisciplinary Journal of Applied Science
ISSN 1980-993X - doi:10.4136/1980-993X
www.ambi-agua.net
E-mail: ambi-agua@agro.unitau.br

\title{
Morphometric analysis of an Areal Watershed in Taubaté, SP, Brazil
}

\author{
doi: 10.4136/ambi-agua.2322
}

Received: 18 Nov. 2019; Accepted: 26 Dec. 2019

\section{Vicente Rodolfo Santos Cezar ${ }^{1 *}$; Marcelo dos Santos Targa' ${ }^{1}$ Celso de Souza Catelani²}

\author{
${ }^{1}$ Programa de Pós-Graduação em Ciências Ambientais. Universidade de Taubaté (UNITAU), Rua Visconde do \\ Rio Branco, $n^{\circ}$ 210, CEP: 12020-240, Taubaté, SP, Brazil. E-mail: targa.marcelo@gmail.com \\ ${ }^{2}$ Instituto de Pesquisas Ambientais em Bacias Hidrográficas (IPABHi), Est. Mun. Dr. José Luiz Cembranelli, \\ n 5000, CEP: 12081-010, Taubaté, SP, Brazil. E-mail: cscatelani@gmail.com \\ *Corresponding author. E-mail: vrscezar@gmail.com
}

\begin{abstract}
In 1991, the Integrated Water Resources Management System (SIGRHI) in the State of São Paulo adopted the watershed as a territorial unit for studies, integrated planning and sustainable development. The morphometric analysis of small watersheds, which involves the characterization of geometric parameters, relief, drainage network, combined with land use and occupation, may constitute an important model for environmental analysis of larger watersheds. This study aimed at characterization of the morphometry in the Areal river basin, in the city of Taubaté, São Paulo. The study found $1.89 \mathrm{~km}^{2}$ of area, $7.44 \mathrm{~km}$ of perimeter and $3.11 \mathrm{~km}$ in length of the basin axis, which allowed the calculation of the compactness coefficient $(\mathrm{Kc}=1.51)$, form factor, $(\mathrm{F}=0.195)$ and circularity index $(\mathrm{CI}=0.43)$, indicating that under normal precipitation conditions, this basin is unlikely to be flooded, due to the distance from the unit, leading to smaller concentrate outflow. The results obtained for the Maintenance Coefficient $(\mathrm{Cm})$ indicate that $260 \mathrm{~m}^{2}$ is required to maintain each meter of perennial channel. The high values of drainage density $\left(\mathrm{Dd}=3.35 \mathrm{~km} \cdot \mathrm{km}^{-2}\right)$ and sinuosity index ( Is = 0.95) indicate that drainage channels in the area are rectilinear, thus suggesting the occurrence of a high surface runoff associated with high dissection. The analysis of land use and occupation revealed that, from the seven types of vegetation cover, the dominant cover in the Areal basin is $0.756 \mathrm{~km}^{2}(40 \%)$ constituted of pasture, while forest represents $0.580 \mathrm{~km}^{2}$ (31\%), $0.321 \mathrm{~km}^{2}(17 \%)$ of the land cover is constituted of degraded forest. In terms of conservation, the Areal basin is conserved because, besides being located in the environmental preservation area of the Una River Basin, it is located at the meeting of two ecological corridors and is occupied by only 8 families of rural producers. On the other hand, the creation of approximately 120 head of cattle in the upper part of the basin and the existence of gully erosion of the order of $0.018 \mathrm{~km}^{2}(1 \%)$ of the basin area, which led to increased runoff and sediment concentration in the flat areas marginal to the creek of Areal. Based on morphometric analysis, it was concluded that: Areal watershed presents high capacity to form new watercourses and their relief characteristics, with low sinuosity channels and high values of altimetric amplitude, channel gradient, and density. Drainage, allied to the existence of erosive processes, favors sediment flow and transport. Conservation actions are required to control erosion.
\end{abstract}

Keywords: drainage, ecological corridors, environmental science. 


\section{Análise morfométrica de uma bacia hidrográfica regional em Taubaté, SP, Brasil}

\section{RESUMO}

O Sistema Integrado de Gerenciamento de Recursos Hídricos (SIGRHI) do Estado de São Paulo em 1991 adotou a bacia hidrográfica como unidade territorial para estudos, planejamento integrado e desenvolvimento sustentável. A análise morfométrica de pequenas bacias hidrográficas, que envolve a caracterização de parâmetros geométricos, do relevo, da rede de drenagem, aliadas ao uso e ocupação do solo, podem se constituir em importante modelo de analise ambiental para bacias maiores Neste sentido, o presente estudo objetivou caracterizar a morfometria da bacia hidrográfica do ribeirão Areal, no município de Taubaté, São Paulo. Na caracterização morfométrica foi encontrada $1,89 \mathrm{~km}^{2}$ de área da bacia, $7,44 \mathrm{~km}$ de perímetro e $3,112 \mathrm{~km}$ de comprimento do eixo, que possibilitaram o cálculo do coeficiente de compacidade $(\mathrm{Kc}=1,51)$, fator de forma, $(\mathrm{F}=0,19)$ e índice de circularidade encontrado, ( IC $=0,43)$ indicando que em condições normais de precipitação, essa bacia é pouco suscetível a enchentes, pois devido ao afastamento da unidade, concentram menor deflúvio. Os resultados obtidos para o Coeficiente de manutenção $(\mathrm{Cm})$ indicam que são necessários $260 \mathrm{~m}^{2}$ para manter cada metro de canal perene e o elevado valor da densidade de drenagem $\left(\mathrm{Dd}=3.35 \mathrm{~km} / \mathrm{km}^{-2}\right.$ ) e do índice de sinuosidade (Is $=0.953$ ) indica que os canais de drenagem são retilíneos e sugere que há um elevado escoamento superficial associado a uma alta dissecação. A análise do uso e ocupação do solo revelou que a cobertura vegetal dominante na bacia do Areal é de pasto com $0,756 \mathrm{~km}^{2}$ (40\%), floresta com $0,580 \mathrm{~km}^{2}$ (31\%); floresta degradada com $0,321 \mathrm{~km}^{2}(17 \%)$. Em termos de conservação, a bacia do Areal apresenta-se conservada, pois além de situar na área de preservação ambiental da Bacia do Rio Una, está situada no encontro de dois corredores ecológicos e é ocupada por apenas 8 famílias de produtores rurais. Por outro lado, a criação de aproximadamente 120 cabeças de gado bovino na parte mais elevada da bacia e a existência de uma erosão do tipo voçoroca da ordem de $0,018 \mathrm{~km}^{2}(1 \%)$ da área da bacia tem ocasionado o aumento do escoamento superficial e concentração de sedimentos nas áreas planas marginais ao ribeirão do Areal. Com base na análise morfométrica pôde-se concluir que: a bacia hidrográfica do Areal apresenta alta capacidade de formar novos cursos d'água e suas características de relevo, com canais de baixa sinuosidade e elevados valores de amplitude altimétrica, gradiente de canais, e densidade de drenagem aliadas a existência de processos erosivos favorecem ao escoamento e transporte de sedimento, são necessárias a adoção de ações de conservação para o controle de erosões.

Palavras-chave: ciências ambientais, corredores ecológicos, drenagem.

\section{INTRODUCTION}

The functioning of the hydrological cycle in a watershed is dependent on geomorphological features (shape, relief, area, geology, drainage network, soil type and vegetation cover), as well as anthropic use in occupation (Lima, 1986). According to Santos et al, (2012) the Water Resources Policy of the state of São Paulo (Law 7663/91), establishes a hydrographic division composed by 21 Water Resources Management Units (UGRHIs) and prioritizes public supply in the use of water resources (São Paulo, 1991). In the municipality of Taubaté, the Una River basin is the most important contributor to the Paraíba do Sul river (UGRHI 2).

Watersheds are among the main territorial management units for conservation of natural resources and their rational use is of fundamental importance for development, being the most 
important resource to the existence of humans, animals and for irrigation and power generation in the state of Sao Paulo.

The native vegetation cover of the State of São Paulo, particularly because it is the most affected by anthropic activities, has considerably decreased, being close to $15 \%$ of its original territorial extension (Kronka et al., 2005).

Populational growth, urbanization and agricultural processes such as cattle farming, eucalyptus cultivation, among other anthropic activities, have been the main causes of forest reduction, river sedimentation, decreasing of water supply. There is a risk involving the scarcity of the water supply for current and future generations (Santos et al. 2012).

For watershed management, it is important to prioritize the quantification of supply and demand, while the physical features of a watershed constitute elements of hydrological behavior evaluation through establishment of relationships and comparisons between them and the known hydrological data, indirectly determining hydrological values in places where these data are unknown (Villela and Mattos, 1975).

The importance of morphometric parameters analysis resides in the fact that it provides a quantitative approach, leading to a better understanding of hydrological behavior, since the morphometric parameters are indicators of surface runoff capacity (Fiori et al., 2006).

For instance, the catchment area has an influence on the amount of water produced as an outflow. The shape and the relief, however, influence the rate or regime of this production, as well as the sedimentation rate. The character and extent of the channels (drainage pattern) affect sediment availability as well as the rate of runoff formation (Lima, 1986).

In this context, the present work analyzes the morphometry of the Areal watershed. The Areal stream is a tributary of the Sete Voltas River, which consequently discharges into Una, being responsible for supplying part of the water intake for human consumption in the municipality of Taubaté.

\section{MATERIAL AND METHODS}

\subsection{Study area characterization}

The areal watershed is a sub-basin of the Una River, located in the southeastern region of the municipality and represented by Figure 1, State of São Paulo and its disposition. Areal watershed, according to the Master Plan of the municipality and described on the Complementary Law 412/2017, referring to the Rural Zone, according to the Municipality of Taubaté (PMT, 2017).

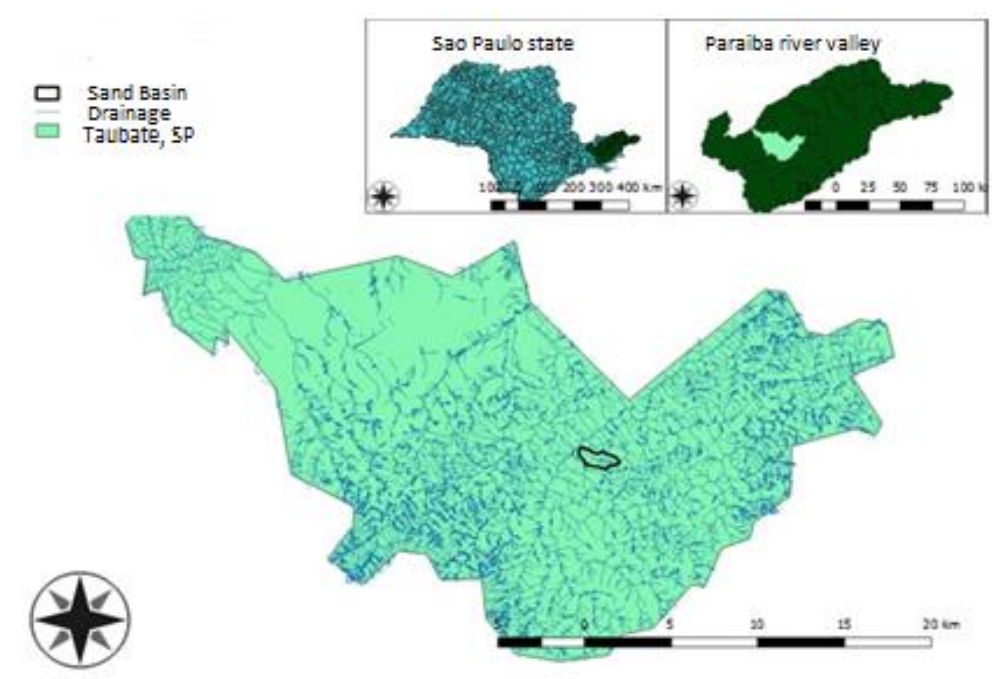

Figure 1. Location of the Areal Basin in the Taubate, SP, Brazil. Source: Lemos et al., 2018. 


\subsection{Climate Classification}

The climate of the region is of the subtropical-humid type - Cwa (Köppen-Geiger), with an average annual precipitation of $1350 \mathrm{~mm}$, with hot and humid summer, from November to February and cold and dry winter in the months of June to August (Fisch, 1999).

Figure 2 describes the monthly precipitation (minimum, maximum and average) in the municipality of Taubaté, SP, over a period of 49 years (1963 to 2012). The straight horizontal lines represent the values of the average precipitation of the minimum, maximum and general average.

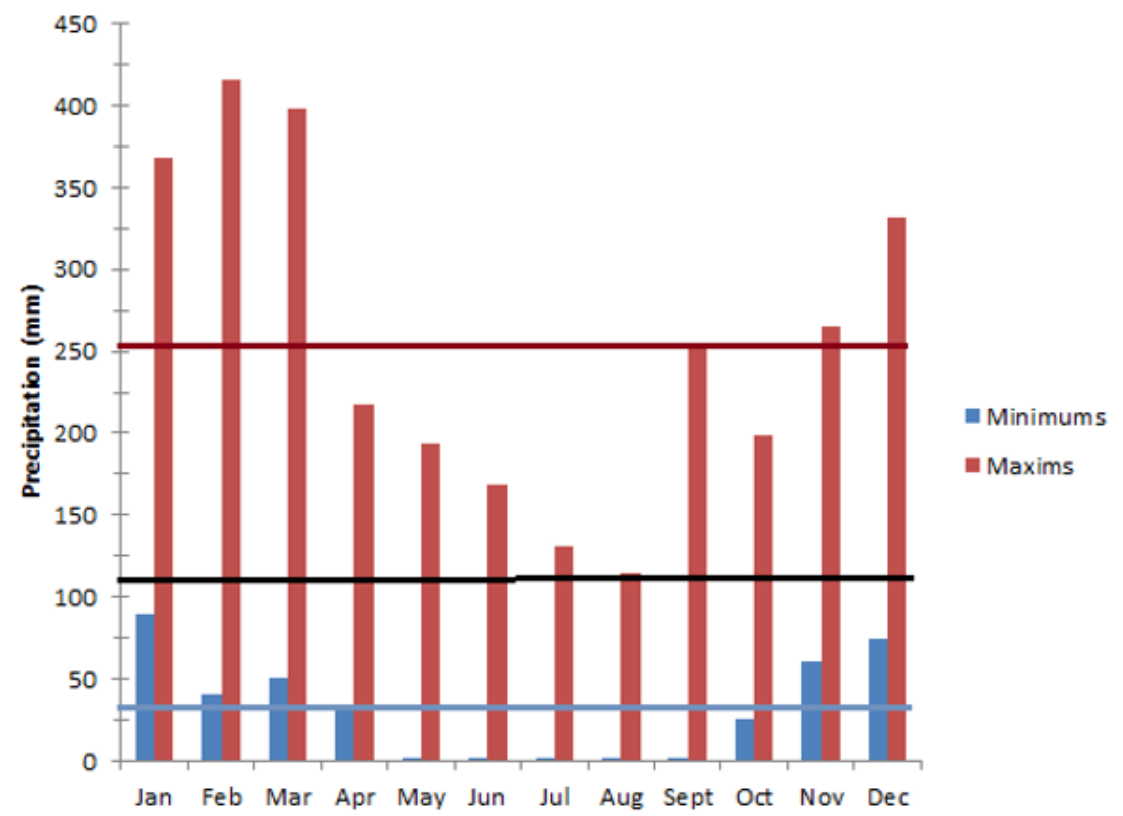

Figure 2. Minimum and maximum monthly rainfall $(\mathrm{mm})$ for Taubaté, SP, compiled for the period 1963 to 2012.

Source: Adapted from DAEE, (2019).

\subsection{Morphometric analysis}

The morphometric analysis of the areal watershed was based on the geometrical, relief and drainage characteristics. In the geometric characterization, the area, the perimeter, the compactness coefficient $(\mathrm{Kc})$, the form factor $(\mathrm{F})$, the circularity index (IC), the hydrographic density (Dh), the number of 1st order channels and the length of the watershed axis.

The compactness coefficient $(\mathrm{Kc})$, which relates the shape of the basin to a circle, is a dimensionless number that varies with its shape, regardless of its size. Thus, the greater the irregularity of the basin, greater will be the compactness coefficient. Since the coefficient of compactness equal to the unit corresponds to a circular basin, it allows the indication of greater or lesser occurrence of floods as it approaches or moves away from the unit (Villela and Mattos, 1975).

The form factor $(\mathrm{F})$ relates to the average width and the axial length of the mouth basin to the farthest point of the spike. Villela and Mattos (1975) mention that a basin with a low form factor is less susceptible to flooding. The circularity index (CI) tends to unity as the basin has a circular shape and decreases as it gets longer (Cardoso et al., 2006). Hydrographic density (Dh) expresses the magnitude of the watershed, indicating the ability to generate new watercourses (Christofoletti, 1969) and suggests the use of $\mathrm{N}$ as the number of first-order channels according to the classification (Strahler, 1952), in order to produce realistic results on the hydrological behavior of the basin.

According to Silva et al. (2002), changes in the drainage system of a watershed may occur due to the small change in river discharge gradient caused by the sudden rise of the 
watershed discharge, due to flooding associated with large-scale deforestation upstream, which may lead to basal erosion of the concave margins and the formation of sediment banks on the downstream convex margins.

The relief characterization of the Areal watershed was determined by the maximum, minimum and average altitude, the altimetric amplitude, the sinuosity index, the channel gradient and the relief ratio. The sinuosity index (Is) expresses the flow velocity of the main channel and according to Freitas (1952), Is values close to unity indicate rectilinear channels, while Is values greater than 2 indicate sinuous channels and intermediate values indicate transitional forms. The channel gradient $(\mathrm{Gc})$ is intended to indicate the declivity of the watersheds of the basin (Horton, 1945; Freitas, 1952). The relief ratio (Rr) is the ratio between the altimetric amplitude of the basin and the length of the main channel. Drainage density (Dd) is the relationship between the total length of channels and the basin area (Table 1). According to Horton (1945), for its calculation, all rivers (perennial and temporary) must be considered.

Table 1. Indicators of morphometric characterization of watersheds.

\begin{tabular}{|c|c|c|}
\hline $\begin{array}{l}\text { Morphometric Characterization } \\
\text { Indexes }\end{array}$ & Equations & Parameters \\
\hline Compactness coefficient $(\mathrm{Kc})$ & $K c=0.28 x \frac{P}{\sqrt{A}}$ & \multirow{9}{*}{$\begin{array}{l}\mathrm{P}=\text { Basin perimeter in } \mathrm{km} \\
\mathrm{A}=\text { Basin area in } \mathrm{km}^{2} \\
\mathrm{~L}=\text { Axial length of basin in } \mathrm{km} \\
\mathrm{N}=\text { Number of rivers or channels } \\
\mathrm{Lc}=\text { length of main channel in } \mathrm{km} \\
\mathrm{Lv}=\text { vector length of main channel in } \\
\mathrm{km} \\
\mathrm{Rr}=\text { Relief ratio in m.km }{ }^{-1} \\
\mathrm{Hm}=\text { Altitude amplitude in } \mathrm{m} \\
\mathrm{Lc}=\text { Length of main channel in } \mathrm{km} \\
\mathrm{Lt}=\text { Total Length of } \\
\mathrm{Dd}=\text { Drainage Density }\end{array}$} \\
\hline Form Factor $(\mathrm{F})$ & $F=\frac{A}{L^{2}}$ & \\
\hline Circularity Index (CI) & $I C=\frac{12.57 x A}{P^{2}}$ & \\
\hline Hydrographic density (Dh) & $D h=\frac{N}{A}$ & \\
\hline Sinuosity Index (Is) & $I s=\frac{L c}{L v}$ & \\
\hline Channel Gradient (Gc) & $G c=\frac{A \max }{L c}$ & \\
\hline Relief Ratio (Rr) & $R r=\frac{H m}{L c}$ & \\
\hline Drainage Density (Dd) & $D d=\frac{L t}{A}$ & \\
\hline Maintenance coefficient (Cm) & $C m=\frac{1}{D d}$ & \\
\hline
\end{tabular}

To characterize the drainage network, the length of the main channel, the total length of the channels, the vector length of the main channel, the drainage density and the order of the basin were determined. According to Christofoletti (1969), high Dd values indicate areas with little infiltration and better channel structure. From the drainage density it is possible to calculate the Maintenance Coefficient $(\mathrm{Cm})$, which represents the required area that the basin must have to maintain each meter of drainage channel perennial. The order of the watercourses of the basin was determined using the methodology described by Strahler (1952), in which the channels without tributaries are called first order, the second order 
channels originate at the confluence of first order channels. third channels arise from the confluence of two second order channels, fourth order channels originate from the confluence of two third order channels and so on.

\subsection{Soil Characterization}

The Areal watershed has a single soil type, the moderately A Eutrophic Red-Yellow Argisol (IF, 2010) and its average physical features, as determined by Cezar and Targa (2018) are particle density $(2.57 \mathrm{~g} . \mathrm{cm}) .-3)$, soil density $(1.14 \mathrm{~g} . \mathrm{cm}-3)$, total porosity $(55.74 \%)$, and sandy loam clay texture composed of $25 \%$ clay, $17 \%$ silt and $58 \%$ sand. The hydrological soil classification of Sartori et al. (2005) indicates that these are type B soils with moderate infiltration rate.

\section{RESULTS AND DISCUSSION}

The total area of occurrence of the different types of vegetation cover and the areas of urban occupation in the Areal watershed, with the use classes' definition present in this work, were adapted from the land use and occupation map (Figure 3) by Lemos et al. (2018).

In Figure 3, it can be seen that the nine most relevant land use and land cover classes in the Areal basin, in order of magnitude, are: the pasture class with the largest area occupied in the watershed (40\%); Tropical forest, which is composed of secondary native forest vegetation in medium stage of development (31\%); Degraded forest consisting of native secondary trees in anthropic use for cattle and horses (17\%); and the Eucalyptus class (5\%) that occupies the sloping areas.

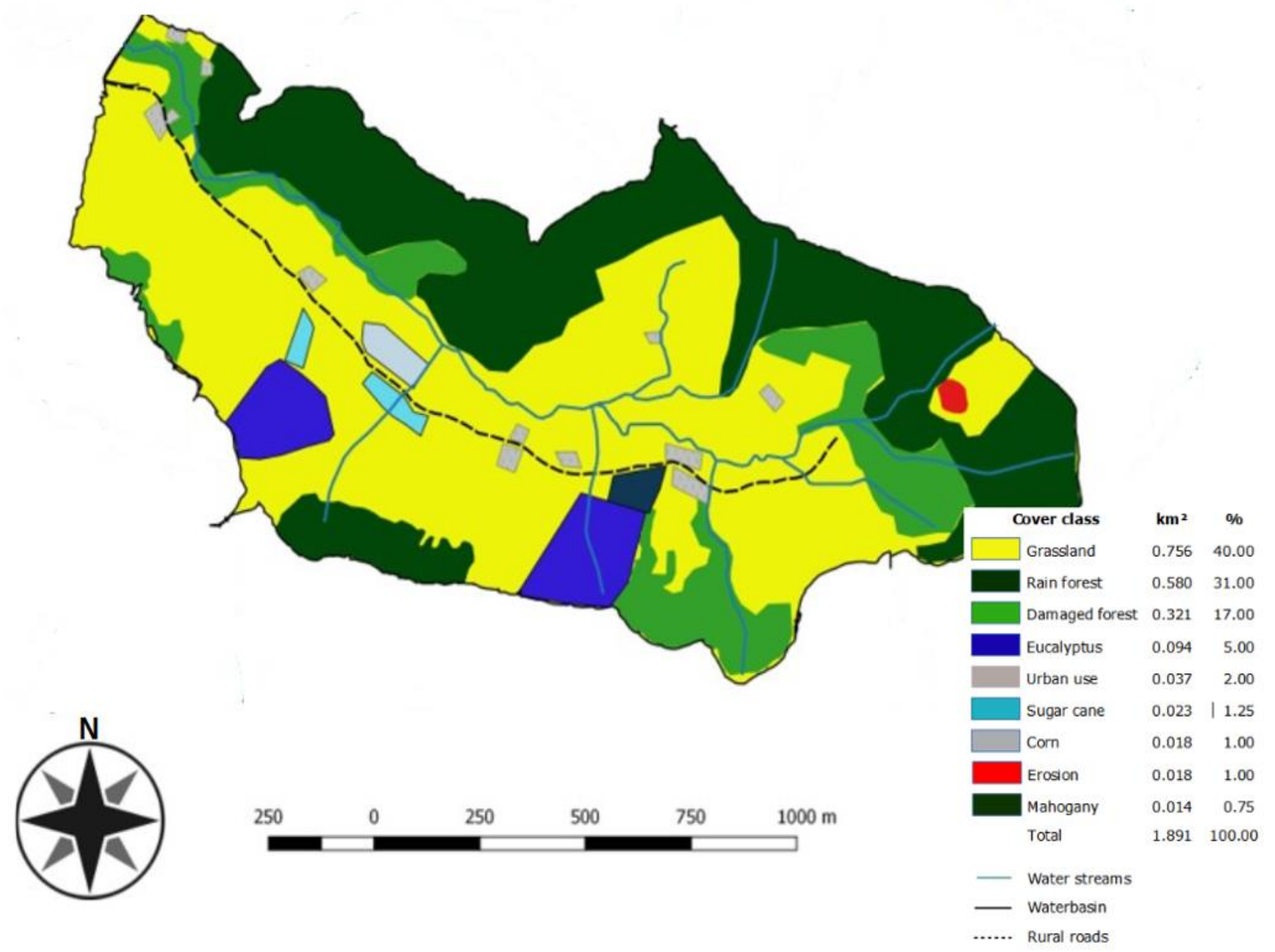

Figure 3. Land use and occupation classes of the Areal basin in Taubate, SP. Source: Adapted from Lemos et al. (2018). 
Occupancy with building facilities (stables, residences and sheds for machinery and equipment shelters) represents an area of $1 \%$, and for this class of use and occupation, it can be said that the anthropic impact on the basin is small, with 5 families (approximately 20 people) live in it.

Water is collected from existing springs throughout the Areal basin to supply domestic animal husbandry. According to Cezar and Targa (2019), using the float method, the flow rate was $8.6 \mathrm{~m}^{3} \cdot \mathrm{h}^{-1}$. It is observed that, for the Areal stream, implementation of conservation measures in short-medium term are needed in order to minimize the problems of evaporation and riparian protection of its banks.

The soil of the basin is Argisol type, with its physical limitations related to shallow depth and presence of gravel or pebbles on the surface, especially in the steepest reliefs. In areas covered by pastures, there is a high rate of degradation and erodibility, especially associated with cattle walking (Figures $4 \mathrm{a}$ and $\mathrm{b}$ ). In this regard, care should be taken in the use of these soils. These aspects, associated with low infiltration capacity in pasture areas, as already determined by Sales and Targa (2017), can promote considerable sediment inputs in floodplain areas.
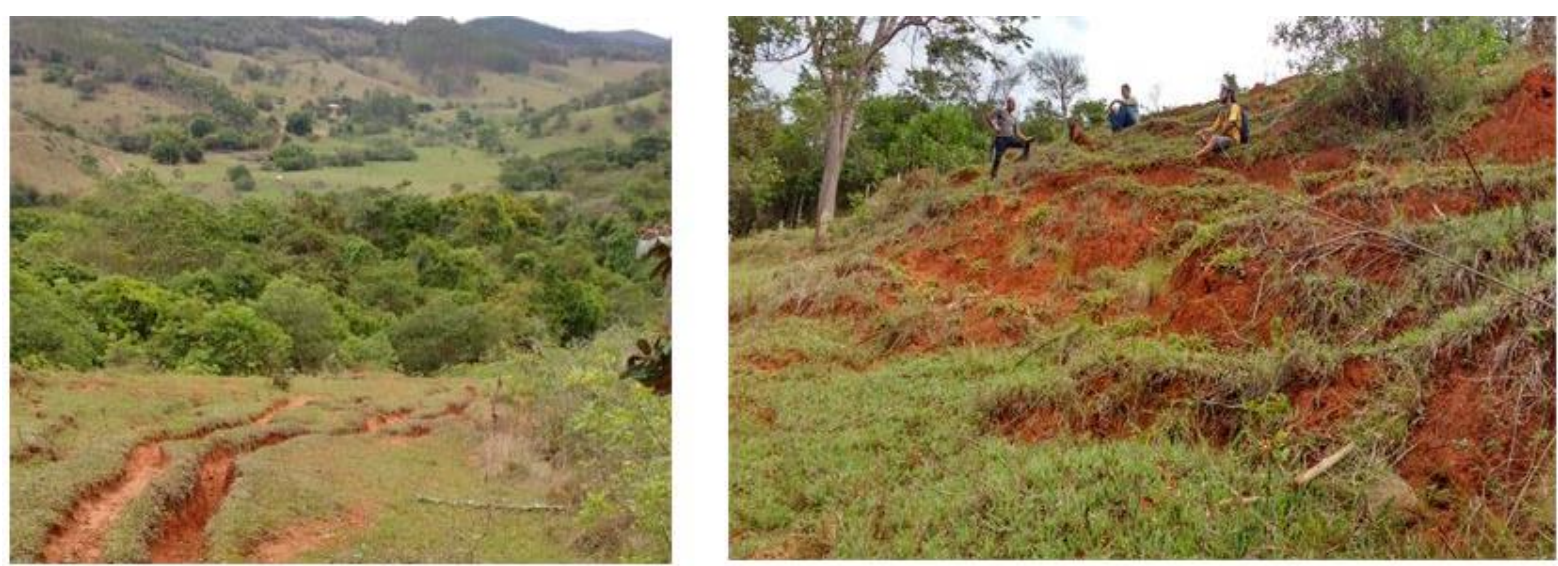

Figure 4. Erosive processes caused by cattle walking in pasture area preferably (a) and randomly (b).

In the land use and occupation map of the Areal basin, erosion class was also defined due to the occurrence of a gully erosion that occupies $1 \%$ of the total area and is located at high altitude. This erosion already existed in the fifties, after the removal of the forest in the production of part of the coal used to feed locomotives transporting extracted natural resources and passengers between the states of Rio de Janeiro and São Paulo, and partially for the introduction of coffee culture by the opening of lanes that linked the agricultural area to the grain drying yards on the Pasto Grande Farm in a neighboring watershed. This gully was registered by aerial photography through the usage of TerraFoto (1972), as shown in Figure (5 a, b).

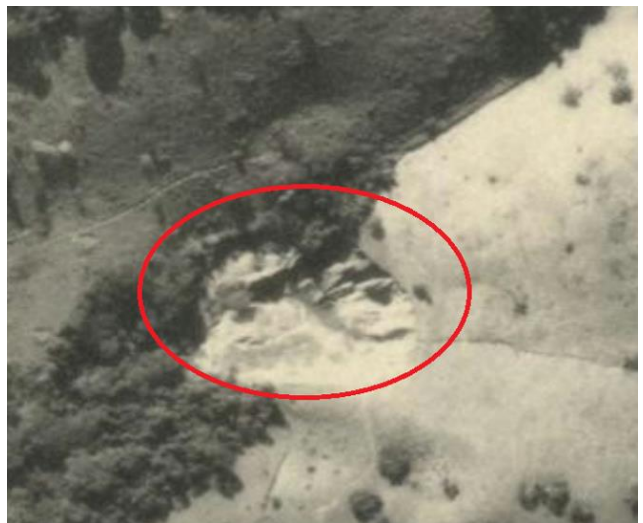

(a) 1973

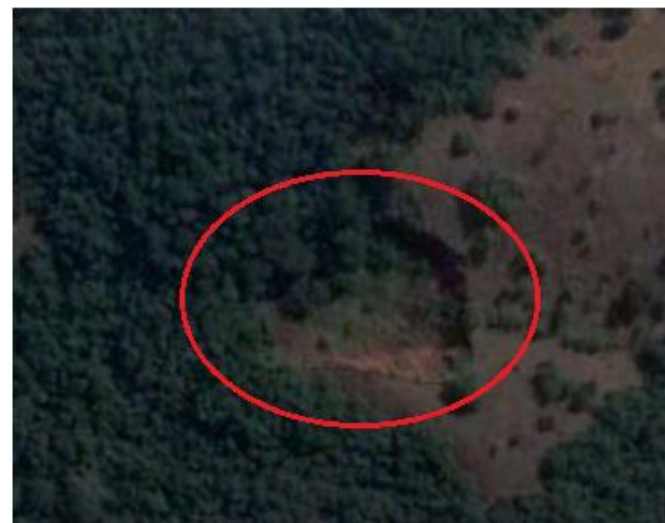

(b) 2017

Figure 5. Gully-type erosion in the Areal basin in Taubate, SP (a) Terrafoto Aerial Photography (1973) and b Google Earth Image (2017). 
The presence of tropical forest type vegetation is important, as it grants water infiltration and aquifer supply, as already determined by water balance (Targa et al., 2019). However, the pasture areas in the basin, which are used to raise 120 head of beef cattle, have a high degree of compaction and soil degradation with deep furrows that favor greater runoff and erosion. In Figure 6, a flat area, marginal to the sandy stream and near the basin exit due to erosion processes in the basin, has received much sediment in the last two years, so that fence posts placed on the property boundary have two wires under a sediment layer.

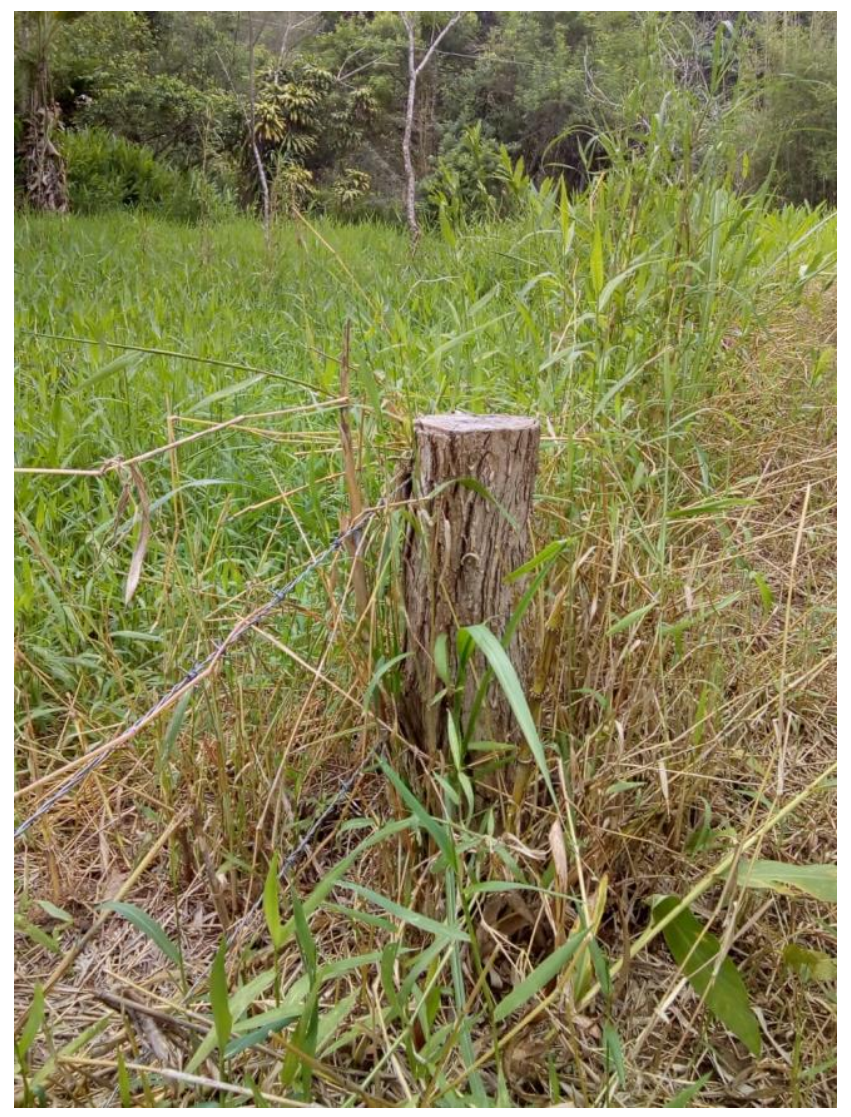

Figure 6. Stake of wire fence in the marginal area of the sediment-covered sandy stream.

The results of morphometric characterization of the Areal watershed are presented in Table 2. In terms of geometric characterization, the compactness coefficient $(\mathrm{Kc}=1.51)$ and the form factor $(\mathrm{F}=0.19)$ were obtained for the Areal watershed, which, according to Santos et al. (2013), under normal rainfall, did not cause flooding. The result of this index is reinforced by that of circularity $(\mathrm{IC}=0.429$ ), because the distance from the unit indicates that the basin does not tend to have a circular shape, i.e., they have a longer shape and, therefore, according to Villela and Mattos (1975), have lower concentration of defluvial outflow.

Hydrographic density of channels $\left(3.35 \mathrm{~km}^{-2}\right)$ was found and, therefore, is considered high (Lollo, 1995), with great capacity to generate new watercourses (Lana, 2001).

The high altimetric amplitude value $(\mathrm{Hm}=170 \mathrm{~m})$, as observed, tends to favor rapid flow. This result is reinforced by the high value found for the channel gradient $(\mathrm{Gc}=260 \mathrm{~m}$ ) and the relief ratio $(\mathrm{Rr}=0.544)$.

The sinuosity index of the channel (Is) is related to the flow velocity in the drainage channels and, in short, to its relationship with the soil in the production of erosion. The drainage channels of this basin are rectilinear in shape because the Is found was 0.953. In terms of channels, it is a third order basin, with a high drainage density of $3.35 \mathrm{~km} . \mathrm{km}-2$, 
suggesting that there is a high surface runoff associated with high dissection (Beltrame, 1994) that indicate the degree of anthropic manipulation, mainly due to cattle raising in forested areas, more inclined, and influencing the supply and transport of sediments (Santos et al. 2012).

In terms of hydrodynamic balance, the maintenance coefficient $\left(\mathrm{Cm}=0.302 \mathrm{~m}^{2}\right) \mathrm{e}$ indicates that $0.302 \mathrm{~m}^{2}$ is required to maintain perenniality of each meter of areal watershed channel. As can be inferred from Figure 3, the average monthly and annual rainfall in 49 years of observation were $114 \mathrm{~mm}$ and $1286 \mathrm{~mm}$, respectively. In the driest period, from April to September (Figure 2), the monthly average rainfall is around $60 \mathrm{~mm}$, while in the wettest period, from October to March, the monthly average rainfall reaches $180 \mathrm{~mm}$. Evaluation of the 12 minimum and maximum precipitation values over 49 years provides the study with the averages of $30 \mathrm{~mm}$ and $254 \mathrm{~mm}$, respectively. This indicates that in the rainy season, and in times of heavy rainfall, there are more favorable conditions for runoff than infiltration. Thus, the type of use and coverage may influence water production capacity of the basin. Therefore, its conservation status is very important.

Table 2. Morphometric characteristics of the Areal watershed.

\begin{tabular}{|c|c|c|c|c|}
\hline & Morphometric indexes & Symbols & Units & Areal Watershed \\
\hline \multirow{8}{*}{ Características geométricas } & Area & A & $\mathrm{km}^{2}$ & 1.890 \\
\hline & Perimeter & $\mathrm{P}$ & $\mathrm{km}$ & 7.440 \\
\hline & Number of 1st Order Channels & $\mathrm{N}$ & - & 8 \\
\hline & Basin shaft length & $\mathrm{L}$ & $\mathrm{km}$ & 3.150 \\
\hline & Compactness coefficient & $\mathrm{Kc}$ & - & 1.510 \\
\hline & Form factor & $\mathrm{F}$ & - & 0.195 \\
\hline & Circularity Index & $\mathrm{IC}$ & - & 0.429 \\
\hline & Hydrographic density & $\mathrm{Dh}$ & channels. $\mathrm{km}^{-2}$ & 4.232 \\
\hline \multirow{7}{*}{ Relief Features } & High altitude & Hmax & $\mathrm{m}$ & 810 \\
\hline & Average altitude & Hmed & $\mathrm{m}$ & 725 \\
\hline & Minimum altitude & Hmin & $\mathrm{m}$ & 640 \\
\hline & Altitude Amplitude & $\mathrm{Hm}$ & $\mathrm{m}$ & 170 \\
\hline & Sinuosity Index & Is & $\mathrm{m} \cdot \mathrm{m}^{-1}$ & 0.953 \\
\hline & Channel Gradient & $\mathrm{Gc}$ & $\%$ & 260.282 \\
\hline & Relief Ratio & $\mathrm{Rr}$ & $\mathrm{m} . \mathrm{km}^{-1}$ & 0,544 \\
\hline \multirow{6}{*}{ Drainage Characteristics } & Length of main channel & $\mathrm{L}$ & $\mathrm{km}$ & 3.112 \\
\hline & Total length of channels & $\mathrm{Lt}$ & $\mathrm{km}$ & 6.337 \\
\hline & Vector length of main channel & Lv & $\mathrm{km}$ & 3.225 \\
\hline & Drainage Density & Dd & $\mathrm{km} \cdot \mathrm{km}^{-2}$ & 3,351 \\
\hline & Maintenance coefficient & $\mathrm{Cm}$ & $\mathrm{m}^{2} \cdot \mathrm{m}^{-1}$ & 0,302 \\
\hline & Basin Order & & - & 3 \\
\hline
\end{tabular}

\section{CONCLUSION}

Based on the morphometric analysis, it was concluded that: Areal watershed has high capacity to form new watercourses, but is not subject to flooding under normal precipitation conditions. Its features of relief, with channels of low sinuosity and high in altimetric amplitude, the gradient of channels, allied with drainage density and the existence of erosive processes favor the sediment flow and transport. Although there is a difference of $46 \%$ in terms of forest cover and degraded forest in the basin, conservation measures are required for erosion control. 


\section{REFERENCES}

ALVES, J. M. P.; CASTRO, P. T. A. Influência de feições geológicas na morfologia da bacia do rio Tanque (MG) baseada no estudo de parâmetros morfométricos e análise de padrões de lineamentos. Revista Brasileira de Geociências, v. 33, n. 2, p. 117-127, 2003.

BELTRAME, A. V. Diagnóstico do meio ambiente físico de bacias hidrográficas: modelo de aplicação. Florianópolis: Ed. da UFSC, 1994. 112 p.

CARDOSO, C. A.; DIAS, H. C. T.; SOARES, C. P. B.; MARTINS, S. M. Caracterização morfométrica da bacia hidrográfica do rio Debossan, Nova Friburgo - RJ. Revista Árvore, Viçosa - MG, v.30, n.2, p. 241-248, 2006.

CEZAR, V. R. S. \& TARGA, M. S. Bacia hidrográfica do rio Una e microbacia hidrográfica do Areal: diagnóstico e convivência permacultural para à proteção da qualidade e quantidade de água no sistema. Relatório do Estágio Pós-doutoral em Ciências Ambientais (Pós-graduação em Ciências Ambientais) - Universidade de Taubaté, São Paulo, 2018.

CEZAR, V. R. S. \& TARGA, M. S. Bacia hidrográfica do rio Una e microbacia hidrográfica do Areal: diagnóstico e convivência permacultural para à proteção da qualidade e quantidade de água no sistema. Relatório do Estágio Pós-doutoral em Ciências Ambientais (Pós-graduação em Ciências Ambientais) - Universidade de Taubaté, São Paulo, 2019.

CHRISTOFOLETTI, A. Análise morfométrica de bacias hidrográficas. Rev. Geomorfol., Campinas, v.18, n.9, p. 35-64, 1969.

DAEE, Dados pluviométricos de Taubaté. Banco de Dados Hidrometeorológicos do Estado de São Paulo. Departamento de Águas e Energia Elétrica do Estado de São Paulo, 1999.

FIORI, A. P.; NUNES, F. G.; RIBEIRO, N. C. Propriedades morfométricas e aspectosfísicos da bacia hidrográfica do Rio Atuba: Curitiba-Paraná. In: VI Simpósio Nacional de Geomorfologia. Proceedings[...] Goiânia, GO, 2006. 10p.

FISCH, G. F. Distribuição da precipitação em Taubaté (SP). Universidade de Taubaté, Revista Biociências, vol.5, $\mathrm{n}^{\circ}$ 2, 1999.

FREITAS, R. O. Textura de drenagem e sua aplicação geomorfológica, Boletim Paulista de Geografia, v.11, p. 53-57, 1952.

HORTON, R. E. Erosional development of streams and their drainage basin: hydrophysical approach to quantitative morphology. Geological Society of America Bulletin, v.56, p. 807-813, 1945.

KRONKA, F. J. N.; NALON, M. A.; MATSUKUMA, M. M.; KANASHIRO, M. M.; YWANE, M. S. S.; LIMA, L. M. P. R. Monitoramento da vegetação natural e do reflorestamento no Estado de São Paulo. In: XII Simpósio Brasileiro de Sensoriamento Remoto, Proceedings[...] Goiânia, Brasil, 16-21 abril 2005, INPE, p. 1569-1576.

LANA, C. E.; ALVES, J. M. de P.; CASTRO, P.T.A. Análise Morfométrica da Bacia do Rio do Tanque, MG-BRASIL. REM. Ouro Preto-MG, Vol 54(2), p. 121-126, 2001.

LEMOS, H. M. S.; PEREIRA, L. F. S.; CEZAR, V. R. S.; TARGA, M. S. Mapeamento Ambiental da Bacia do Areal no Município de Taubaté, SP. Repositório de Ciências 
Ambientais, [S.1.], v. 1, n. 1, dec. 2018. Disponível em: <http://www.agro.unitau.br/repositorio/index.php/rca/article/view/27>. Acesso em: 06 nov. 2019.

LIMA, W. P. Princípios de hidrologia florestal para o manejo de bacias hidrográficas. Piracicaba: Escola Superior de Agricultura Luiz de Queiroz, 1986. 242p.

LOLLO, J. A. O uso da técnica de avaliação do terreno no processo de elaboração do mapeamento geotécnico: sistematização e aplicação na quadrícula de Campinas. Tese de Doutorado, São Carlos, Universidade de São Paulo, Escola de Engenharia de São Carlos, 1995.

OLIVEIRA, J. B. Solos do Estado de São Paulo: descrição das classes registradas no Mapa pedológico. Campinas: Instituto Agronômico, 1999. Boletim Científico, 45. $112 \mathrm{p}$.

PMT. PLANO DIRETOR FÍSICO DO MUNICÍPIO DE TAUBATÉ - LEI $\begin{array}{lllllll}\text { COMPLEMENTAR } & 412 & \text { DE } & 12 & \text { DE } & \text { JULHO } & \text { DE }\end{array}$ <https://issuu.com/prefeituradetaubate/docs/pmma_final_2_2_>, acesso em: 21/07/2018

SALES, P. A.; TARGA, M. S. Infiltração de água em diferentes usos e ocupação dos solos na bacia do rio Una em Taubaté, SP. Repositório de Ciências Ambientais, [S.1.], v. 1, n. 1, p. 1-13, dec. 2017. Disponível em: <http://www.agro.unitau.br/repositorio/ index.php/rca/article/view/5>. Acesso em: 12 nov. 2019.

SANTOS, A. M.; TARGA, M. S.; BATISTA, G.T., DIAS, N. W. Analise morfométrica das sub-bacias hidrográficas Perdizes e Fojo no município de Campos Jordão, SP, Brasil. Revista Ambiente \& Água, Taubaté, v. 7, n. 3, p. 195-211, 2012. (http://dx.doi.org/10.4136/ambi-agua.945)

SÃO PAULO (estado). Política Estadual de Recursos Hídricos. Lei 7663 de 30 de dezembro de 1991. São Paulo, 19p. 1991.

SÃO PAUlO (Estado). Departamento de Águas e Energia Elétrica - DAEE. Banco de Dados Hidrometeorológicos do estado de São Paulo. Dados pluviométricos de Taubate. São Paulo, 1999. Disponível em: < http://www.hidrologia.daee.sp.gov.br/>. Acesso em: 21 nov. 2019.

SARTORI, A.; GENOVEZ, A. M.; LOMBARDI NETO, F. Classificação Hidrológica de Solos Brasileiros para a Estimativa da Chuva Excedente com o Método do Serviço de Conservação do Solo dos Estados Unidos. Parte 2: Aplicação. Revista Brasileira de Recursos Hídricos, v. 10, p. 19-29. 2005.

SETZER, J. Atlas Climático e Ecológico do Estado de São Paulo. Comissão Interestadual da Bacia Paraná-Uruguai, 1966. 61p.

STRAHLER, A.N. Hypsometric analysis and erosional topography. Geological Society of America Bulletin, v.63, p. 1117-1142, 1952.

TARGA, M. S.; POHL, E.; ALMEIDA, A. A. S. Water balance in soil covered by regenerating rainforest in the Paraíba Valley region, São Paulo, Brazil. Revista Ambiente \& Água, v. 14, n. 6, p. 1-11, nov. 2019. ISSN 1980-993X. (http://dx.doi.org/10.4136/ambi-agua.2482). 
TERRA FOTO. Fotografia aérea da região do Vale do Paraiba. Esc. 1:25.000. TerraFoto SA. (1973).

VILLELA, S. M.; MATTOS, A. Hidrologia aplicada. São Paulo: Mc Graw-Hill do Brasil, 1975. 